\title{
Changing Organizational Culture to Establish Sustainability
}

In business management, one key factor is quite often overlooked: organizational culture. It influences the behavior of managers and employees, how they perceive and address the firm's internal and external challenges, and attitudes towards change. To establish a truly sustainable business model, decisive corporate change is needed.

Bernhard Fietz, Edeltraud Günther 
Organizational culture is of utmost importance for the success of corporate environmental management initiatives and the achievement of corporate sustainability. The implementation of environmental practices and guidelines must be embedded into the values and beliefs of the organizational culture (Johnstone 2018) to enable the required awareness as well as ongoing dialogue and communication about environmental issues. Moreover, organizational culture is also a disciplining instrument and control mechanism which may foster the likelihood of long-term success of corporate environmental management initiatives. It affects the behavior and decision making of managers and thus the firm's strategic orientation, performance, procedures, and attitudes towards change and innovation.

\section{What is organizational culture?}

Organizational culture is comprised of shared values, norms, assumptions, and beliefs that affect managers and employees in their daily operations. It influences behavior with regard to interactions with other members of the organization and external stakeholders. In sum, organizational culture influences corporate practice. It provides guidance on the perception and the resolution of problems, as well as on decision-making. In short, organizational culture shapes the pattern of social life within the firm, for example employee commitment to the organization and its goals and values, as well as the creation of a group feeling among managers and employees. Every organization has an organizational culture. It is either explicit and thus actively managed and controlled, or implicit and not given further attention by management, leading to a lack of attempts to actively change it (Schein 2010).

The model most commonly applied in business management research to classify and quantify the rather broad and general term of organizational culture is the competing values framework (see figure 1). This model quantifies organizational culture into four specified culture types to enable empirical analyses (Henri 2006; Linnenluecke/Griffiths 2010):

Adhocracy cultures foster innovation and willingness to try new things, take risks, and think out of the box.

Bureaucracy cultures have an administrative approach with detailed procedures and processes in combination with predictability to provide stability and efficiency.

Clan Cultures emphasize loyalty as the key value and foster personal ties and group thinking.

Market cultures are results-driven and focus on competitive actions and goal achievement.

The four culture types can be found in the four quadrants of the competing values framework. They are classified by the categories of flexible versus stable organizational structure and internal versus external organizational focus. Each type focuses on different values and norms and thus different organizational philosophies, strategies, and management styles. A firm can determine its organizational culture type by applying the OCAI survey questionnaire (Cameron/Quinn 2011).

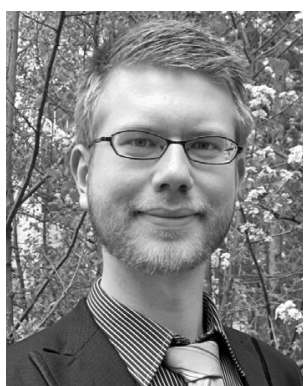

\section{Bernhard Fietz}

Chair of Business Management, especially Sustainability Management and Environmental Accounting, Faculty of Business Management and Economics, Technische Universität Dresden (TU Dresden) E-Mail: bernhard.fietz@tu-dresden.de

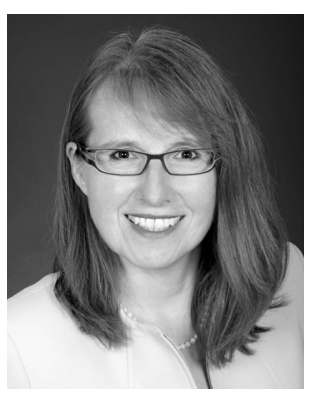

\section{Prof. Dr. Edeltraud Günther}

Founder and Head of the Center for Sustainability Assessment and Policy PRISMA Institute for Integrated Management of Material Fluxes and of Resources (UNUFLORES), United Nations University, Dresden

E-Mail:guenther@unu.edu 


\section{Firms should adapt either an adhocracy or a bureaucracy culture to promote corporate sustainability initiatives.}

In most cases, one culture type is dominant and may include some characteristics of the other types. Every organization has its own combination of different values, beliefs, and rules and thus, a distinct organizational culture (Schein 2010). If a company has, for example, a strong bureaucracy culture valuing formal procedures and regulations, it may also include some elements of a clan culture, such as emphasizing loyalty as a core value. In turn, this company may have a weak adhocracy culture, value adaptability to a lesser extent, and be hesitant about change initiatives.

A hybrid organizational culture that combines and emphasizes characteristics of different organizational culture types equally may also be effective in its organizational context. Moreover, firms with a strong overemphasis of only one distinct organizational culture type may become dysfunctional (Linnenluecke /Griffiths 2010). For example, a strong focus on bureaucracy and stability can lead to an inability to cope with changing business environments.

It cannot be concluded that one cultural type of the competing values framework is generally better than another.

\section{The influence of the culture type on corporate environmental management}

There is still no unilateral understanding of corporate sustainability and its practical implementation in firms (Hahn/Scheermesser 2006, Johnstone 2018). The corporate environmental management and the organizational culture are context-dependent; there are no general solutions that are applicable to every firm. Organizational culture is highly dependent on the organizational context, which consists of all internal and external factors, such as internal and external stakeholders, market environment or industry sector.

\section{Figure 1 The Competing Values Framework}

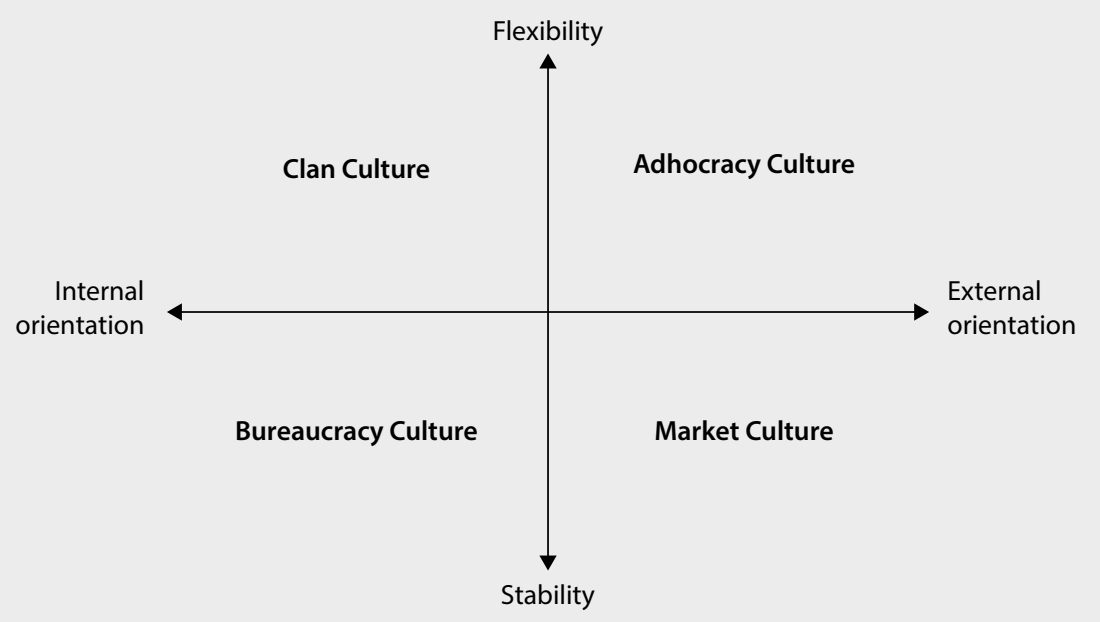

Source: Cameron/Quinn 2011 
It is important to consider that the competing values framework itself does not promote a particular type of organizational sustainability culture. Nevertheless, each of the four culture types has distinct implications for the corporate environmental management:

\section{Adhocracy cultures}

Adhocracy cultures focus on innovation, experimentation, and also risktaking to achieve corporate sustainability with an integrated, comprehensive corporate sustainability strategy. This, in turn, involves a process of organizational learning and change, which can improve the corporate environmental performance on multiple dimensions and may lead to a competitive advantage (Linnenluecke/Griffiths 2010). Adhocracy cultures break through existing norms, are suitable for dynamic business environments, and are more likely to promote corporate sustainability. They are suitable for startups and firms that operate in industrial sectors with dynamic market environments as they promote flexible processes, pioneering initiatives, and an innovative working atmosphere.

\section{Bureaucracy cultures}

Bureaucracy cultures emphasize efficiency, for example elimination of waste and redundancies, and a simplification of products, services, and processes to reduce costs to achieve corporate sustainability. The sustainability strategy of bureaucracy cultures is compliance- and efficiency-driven; tasks and responsibilities are clearly defined and delegated top-down. Nevertheless, such narrow focus will only provide limited competitive advantage because the aforementioned efficiency measures can be easily copied by competitors. Moreover, that may delay the implementation of new technologies, changes or innovation that are necessary for the success of corporate environmental management initiatives (Cameron/Quinn 2011; Vodonick 2018).

\section{"Every organization has its own combination of different values, beliefs, and rules and thus, a distinct organizational culture."}

Nevertheless, companies that are already well established in their markets, have a slower pace of change pressure, and focus on stability, efficiency, and smooth-running processes should adopt a bureaucracy culture to be steered most efficiently into a sustainable business direction by adapting and expanding their organizational guidelines.

\section{Clan cultures}

Clan cultures focus on social interaction, interpersonal relations, employee development, and learning and capacity building, such as corporate environmental health and safety initiatives, to facilitate corporate sustainability.

\section{An organizational culture focused on sustainability can be a competitive advantage.}




\section{Summary}

- There is still no unilateral understanding of corporate sustainability and its practical implementation.

- Organizational culture is among the main reasons for the failure of the implementation of corporate sustainability efforts and organizational change programs.

- The behaviour and decision-making of managers and thus the strategic direction of the company and attitudes towards sustainability, change and innovation are influenced by organizational culture.

\section{"Organizational culture influences corporate practice and shapes the pattern of social life within the firm."}

Studies have shown that clan and market cultures are not preferable to promote corporate sustainability (Vodonick 2018); depending on the market environment and internal and external stakeholders, firms should either adopt an adhocracy or a bureaucracy culture.

\section{Organizational culture and corporate environmental management initiatives}

Organizational culture affects the behavior and decision making of managers and thus the firm's strategic orientation, performance, procedures, and attitudes towards change and innovation. Conversely, managers can also shape the organizational culture. They can foster its environmental values and beliefs and include a vision of corporate sustainability that is ingrained into a business vision and mission that creates a common corporate identity. In this case, organizational culture is explicitly controlled. The promotion and support of corporate environmental management initiatives by the top management is of utmost importance. The adoption of corporate sustainability principles necessitates changes in managers' and employees' values and beliefs emphasizing the importance of corporate environmental management initiatives. It also enables change in actual practice towards sustainability throughout the organization. Moreover, there has to be a learning environment within the organization, facilitated by tools such as guidelines and employee training, that can adapt to changing conditions (Linnenluecke/ Griffiths 2010). Environmental values and goals must be embedded in and pursued by all corporate departments to achieve corporate sustainability (Johnstone 2018). Such a comprehensive organizational culture focused on sustainability can be a competitive advantage, for example in developing 
new innovative products and services or increasing reputation and recognition by customers and other external stakeholders. However, the adoption of a comprehensive sustainability culture can be difficult in firms that have strong subcultures in their different departments, for example the sales department compared to the research and development department. These subcultures can be hard to change. In such instances, persistence of the top-management and substantial change efforts that are integrated into corporate strategy are required.

\section{Managerial implications}

Organizational structures and processes for the corporate environmental management are not clearly defined in organizational practice. In some firms, the $\mathrm{CEO}$ is responsible for the corporate environmental management; in others, this responsibility is assigned to the $\mathrm{COO}$, the sustainability department, or even the marketing department. One reason for this might be that there is no unilateral understanding of corporate sustainability in corporate practice. Moreover, the promotion of corporate sustainability requires permanent change. Consequently, the goals and tasks of the whole firm in general and the corporate environmental management in particular need to be clearly defined. The importance of corporate sustainability has to be emphasized by the clear assignment of responsibilities, for example by making the head of the corporate environmental management a board member who can be given the title of Chief Sustainability Manager. Top management support is crucial. As corporate sustainability and organizational culture are context-dependent, managers should be aware that management practices, policies, procedures, and rules that are applied in other firms may be unsuitable for their firm. The implementation of environmental practices and guidelines must be embedded into the values and beliefs of the organizational culture.

Moreover, firms can also implement additional tools and procedures to strengthen corporate environmental management initiatives. For instance, they can publish a corporate sustainability policy, a code of conduct with clear definitions communicating corporate values and goals. They can also integrate environmental goals and their fulfillment in manager and employee evaluations, embed environmental performance indicators into reward and compensation systems, make use of sustainability benchmarking, or create an environmental balanced score card. Further measures include manuals, workshops, and continuous employee training with clear guidelines as a key factor for learning processes for sustainability topics (Linnenluecke/ Griffiths 2010).

Nevertheless, firms also have to be wary of a thin line between reactive environmental initiatives focusing solely on cost reduction, process improvement, resource efficiency, competitor orientation as facilitated by market cultures, and green washing. Increasing consumer awareness and external stakeholder pressure demand a comprehensive corporate sustainability approach, rather than a few isolated measures that mainly focus on financial targets. All internal and external stakeholders should be involved in the cor-

\section{Environmental values and goals must be embedded in and pursued by all corporate departments to achieve corporate sustainability.}


Change in business management and corporate practice is necessary and unavoidable to achieve corporate sustainability. porate environmental management initiatives to achieve a truly sustainable way of doing business.

\section{Change is an opportunity}

There is a broad consensus that change in business management and corporate practice is necessary and unavoidable to achieve a more sustainable way of doing business. The world is permanently changing; there always have been and always will be change: People, political systems, laws, regulations, art, lifestyles, the climate, natural environments, and, of course, organizations and especially firms change. Firms have to change to meet all the demands of the internal and external stakeholders.

\section{"In many cases, environmental issues are treated as only being of secondary importance."}

But many organizations are inherently resistant to change unless it seems to be unavoidable. This is an organizational phenomenon called organizational inertia. As a result of this, most organizational change initiatives fail or only enable insignificant adjustments (Narayan/Adams 2016). Studies have shown that organizational culture is among the main reasons for the failure of organizational change programs (Vodonick 2018); the implementation of tools, techniques, and change strategies alone does not ensure success of corporate environmental management initiatives when the organizational culture is reluctant to change (Linnenluecke/Griffiths 2010).

This is being reinforced by the common perception of Western societies and business managers that consistency, reliability, established routines, and procedures are preferable. Minor changes may be accepted; however, bold change initiatives are viewed with skepticism and are often seen as something problematic that must be avoided. In many cases, environmental issues are treated as only being of secondary importance. Creativity and outof-the-box-thinking are needed to overcome entrenched routines; however, such traits have to be consistently applied. As outlined above, a static business approach that only implements change initiatives when forced by laws and regulations or competitors, is less than ideal. Moreover, after implementing change in a clearly defined transition phase, organizations tend to revert to their static state of business. This can be labeled as a "freeze, unfreeze, and freeze" approach on change (Vodonick 2018). However, the environment does not work this way; change is a permanent process. For example, Asian societies such as Japan, Singapore, South Korea or Taiwan display a much higher readiness to change and to adopt new technologies and ideas. This can also be observed in how these societies deal with the Covid-19-pandemic compared to Western societies. For example, Japanese firms embrace the principle of Kaizen, the continuous improvement of all organizational functions, processes, products, and services involving all organizational members including the top management and the CEO. 


\section{Conclusion}

There is an urgent need for the transformation from a static to a dynamic world view with change as a permanent process in business and society to address the challenges of global climate change and environmental degradation. Organizations must view change as an opportunity rather than a threat. An openness and high readiness for change has to be embedded into the organizational culture and the business strategy. Only an organizational culture that welcomes, embraces, and facilitates change and includes it in its organizational values and beliefs can promote sustainability. Since change itself is unavoidable, firms have to build capabilities to deal with change, unexpected events, and crises, for example by using tools such as scenario planning and employee training. Change is not the problem; insufficient preparation and a reluctant attitude are.

\section{References}

Cameron, K. S./Quinn, R. E. (2011): Diagnosing and changing organizational culture. Based on the competing values framework, 3rd edition, San Francisco.

Hahn, T./Scheermesser, M. (2006): Approaches to corporate sustainability among German companies, in: Corporate Social Responsibility and Environmental Management, 13 (3), pp. 150-165.

Henri, J. F. (2006): Organizational culture and performance measurement systems, in: Accounting, Organizations and Society, 31 (1), pp. 77-103.

Johnstone, L. (2018): Theorising and modelling social control in environmental management accounting research, in: Social and Environmental Accountability Journal, 38 (1), pp. 30-48.

Linnenluecke, M. K./Griffiths, A. (2010): Corporate sustainability and organizational culture, in: Journal of World Business, 45 (4), pp. 357-366.

Narayan, V./Adams, C. A. (2016): Transformative change towards sustainability. The interaction between organisational discourses and organisational practices, in: Accounting and Business Research, 47 (3), pp. 344-368.

Schein, E. H. (2010): Organizational culture and leadership, 2nd edition, San Francisco. Vodonick, J. (2018): The key to organizational sustainability. Nurturing a culture of change, in: Systems Research and Behavioral Science, 35 (4), pp. 458-468.

\section{SpringerProfessional}

Inghels, D. (2020): Sustainability transition for businesses, in: Inghels, D.: Introduction to modeling sustainable development in business processes, Cham, S. 1-28. www.springerprofessional.de/link/18558986

Toniolo, K. et al. (2020): Sustainable business models and artificial intelligence: opportunities and challenges, in: Matos, F. et al. (eds.): Knowledge, people, and digital transformation, Cham, S. 103-117.

www.springerprofessional.de/link/17919544 


\section{Springer Gabler}

T. Grund, A. Schönbohm, K. Tran Unternehmensplanung im Zeitalter der Digitalisierung Ansätze und Erfolgsfaktoren in der Praxis 2020. VIl, 49 S. 1 Abb. Brosch. $€$ (D) $14,99 \mid €$ (A) $15,41 \mid$ CHF 17.00 ISBN 978-3-658-29928-6

$€$ (D) $4,99 \mid$ CHF 5.50 ISBN 978-3-658-29929-3 (eBook)

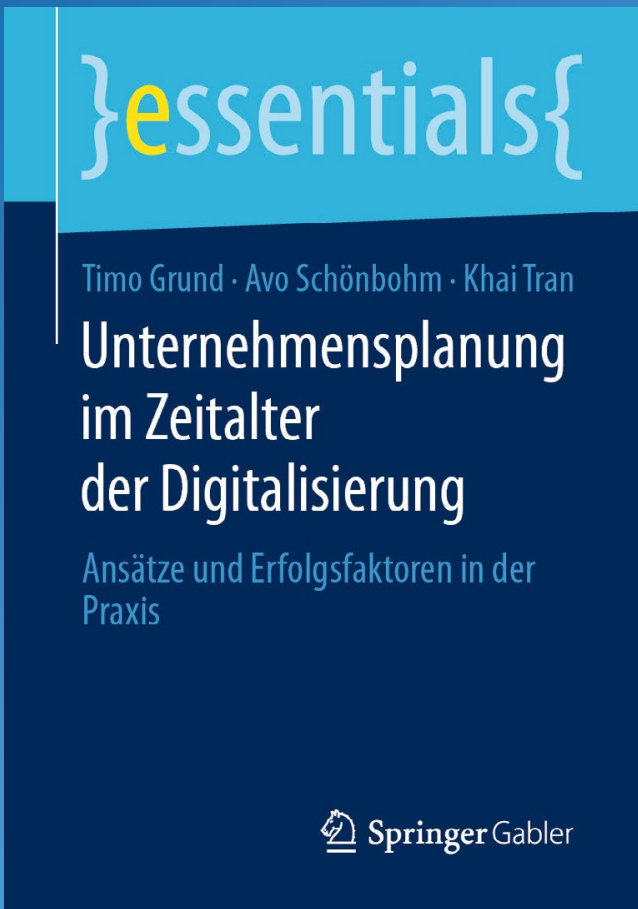

\section{Unternehmensplanung im 21. Jahrhundert}

- Bessere Planung durch neue Technologien?

- Eine Diskussion mit der Praxis

Unternehmen müssen sich dem Druck volatiler Märkte, der digitalen Transformation und einer generellen Entscheidungsunsicherheit stellen. Wer die Zukunft erfolgreich gestalten will, sollte die klassischen Funktionen der Unternehmenssteuerung anpassen, allen voran die Planung. Moderne, digitale Lösungen können den Prozess optimieren, bergen allerdings auch Herausforderungen. In diesem Kontext befassen sich die Autoren zunächst theoretisch mit der Unternehmensplanung. Sie stellen dar, welchen Zweck Planung heutzutage erfüllt und wie neue Technologien die Anforderungen an die Planung und auch diese selbst verändern. Der theoretische Beitrag wird gespiegelt mit einem praxisbezogenen Panel, in dem vier Experten sowohl ihre persönlichen Erfahrungen als auch die Herausforderungen in der Realität diskutieren. Die Autoren: Timo Grund ist Principal mit Fokus auf Corporate Finance \& Strategy sowie Energie bei einer globalen Unternehmensberatung. Prof. Dr. Avo Schönbohm lehrt und forscht als Professor für ABWL mit Schwerpunkt Controlling an der Hochschule für Wirtschaft und Recht Berlin. Khai [...] 